Ann. Zootech., 1980, 29, $\mathrm{n}^{\circ}$ h. s., 85-92.

\title{
Feeding trials describing net requirements for maintenance as dependent on weight, feeding level, sex and genotype
}

\author{
B. BECH ANDERSEN
}

National Institute of Animal Science

Rolighedsvej 25, 1958 Copenhagen V, (Denmark)

\begin{abstract}
By use of data from production experiments it is shown that the maintenance requirement (or weight dependent use of non-productive energy) of growing young bulls depends on the feeding level and the genotype.

It is therefore obvious that these two factors must be taken into consideration when energy standards for growing animals are concerned.

In the testing and selecting of breeding animals it is important to include the feed utilisation and maintenance requirement.

In the performance tests of potential breeding bulls regular recording of feed intake and weight gain during the test period might be a valuable technique.
\end{abstract}

\section{Résumé}

Estimation des besoins énergétiques nets d'entretien

à partir des résultats d'essais d'alimentation; variations en fonction du poids, du niveau d'alimentation, du sexe et du génotype.

A partir de résultats d'essais d'alimentation, on a montré que le besoin d'entretien des jeunes taurillons en croissance (c'est-à-dire le besoin en énergie non productive lié au poids) dépend du niveau d'alimentation et du génotype. C'est pourquoi il faut tenir compte de ces 2 facteurs dans l'établissement des recommandations énergétiques pour les animaux en croissance.

Dans les contrôles de performances et les critères de sélection des reproducteurs, il faut aussi prendre en considération le besoin d'entretien et l'efficacité d'utilisation des aliments. Le contrôle régulier des quantités d'aliments ingérées et du gain de poids peut constituer une technique précieuse. 


\section{Introduction}

In most of the feeding standards for growing animals the energy requirement for maintenance is based on results from balance experiments in respiration chambers. It is technically difficult, however, to measure the maintenance requirement of young growing animals in balance experiments (VAN ES, 1978). The animals are easily stressed by the measuring procedures and normally fed only on a maintenance ration ; they may feel hunger and show abnormal behaviour. Furthermore, balance experiments are expensive and, consequently, they are usually carried out as short term experiments with a relatively small number of animals involved.

During recent years however, extensive factorial experiments including varying final weights, genotypes and feeding levels, have given valuable information. The results from such feeding trials can be an important supplement to the balance experiments and in the present paper I shall describe and discuss results from some of these trials.

\section{I. - Feed efficiency}

Feed efficiency can be expressed as the ratio $\frac{\text { output }}{\text { input }}$, or as its reciprocal feed conversion ratio $\frac{\text { input }}{\text { output }}$, which is more frequently used.

\section{a) Effect of feeding level}

The effect of different levels of feeding intensity on feed efficiency has been examined in several experiments and a survey is given by, among others, ANDERSEN (1978). Most of the experiments show the best feed conversion ratio at moderate feeding levels.

\section{b) Effect of sex}

Bulls are more efficient feed converters than steers, and steers are more efficient than heifers. ANDERSEN (1978) suggested that the relative difference between sexes is reduced with decreasing feeding level.

\section{c) Effect of genotype}

From the numerous experiments on breed comparisons there is a strong indication of breed differences in feed conversion ratio. The within breed coefficient of heritability for feed conversion varies from 0.2 to 0.7 (LANGLET et al., 1967 ; Preston and Willis, 1970 ; LANGHolz and Jongeling. 1972 ; Trappman, 1972). Andersen (1977) has described the feed utilisation as Scandinavian feed unit/kg total gain, carcase gain and lean gain, and showed a genetic coefficient of variation for these traits of 4.7 p. $100,5.1$ p. 100 and 
6.7 p. 100 , respectively. Feed utilisation is included in the breeding programmes in many countries (especially performance tests). In Denmark, for instance, 600 dairy bulls are performance tested each year. In Table 1 some examples on the variation in feed conversion ratio are shown. In the period from $1 \frac{1}{2}$ to 11 months of age, each bull is fed with a total of 1515 feed units but, even on that constant feed intake, the difference between the best and the poorest one third of the bulls is $45 \mathrm{~kg}$ liveweight gain.

TABLE 1

PERFORMANCE TEST RESULTS OF FRIESIAN BULLS AT AALESTRUP BREEDING STATION (ANDERSEN et al., 1979)

\begin{tabular}{|c|c|c|c|c|}
\hline & $\begin{array}{l}\text { Av. daily } \\
\text { gain } \\
\text { (g/day) } \\
\end{array}$ & $\begin{array}{l}\text { Weight in } \mathrm{kg} \\
\text { at } \\
1 \frac{1}{2} \mathrm{mt} 11 \mathrm{mt}\end{array}$ & $\begin{array}{r}\text { F.u. } \\
\text { total } \\
\end{array}$ & $\begin{array}{r}\text { F.u./ } \\
\mathrm{kg} \text { gain }\end{array}$ \\
\hline $\begin{array}{l}\text { Av. } \\
\text { of best } 1 / 3\end{array}$ & 1331 & 459 & 1515 & 3.9 \\
\hline $\begin{array}{l}\text { Av. } \\
\text { of poorest } 1 / 3\end{array}$ & 1175 & 410 & 1514 & 4.4 \\
\hline
\end{tabular}

The probable reasons for the demonstrated effect of feeding level, sex and genotype on feed conversion ratio, can be as a result of differences in composition of the gain, differences in maintenance requirement and/or differences in digestion capacity.

The energy content of fat tissue is about 8 times that of lean meat. Therefore, it is often assumed that leaner animals automatically are the most efficient converters of feed. However, ANDERSEN (1977) has shown that estimated within breeds, body composition has a very small effect on feed conversion. The reason is that within breed variation in fatness is relatively small and that only a limited part of the ME consumed is retained as body tissue. Even rapidly growing animals use most of the consumed feed for maintenance. Therefore, a few percent variation in the fat content of the body has little influence on the total feed conversion ratio. Consequently, the variation in maintenance requirement must be taken into account when feed efficiency in cattle production is discussed.

\section{II. - Maintenance requirement}

HANSSON et al. (1953) demonstrated an effect of both genotype and feeding level on maintenance requirements in an experiment with identical twins. The same results were found by TAYLOR and Young (1968), WeBster et al. (1976) and VERMOREL et al. (1976). 


\section{Danish investigations}

In Danish production experiments with young bulls on individual records of feed consumption, serial slaughtering and complete carcase dissection, the maintenance requirement has been calculated from the following basic regression models :

(1) $\mathrm{EP}=b_{o}+\mathrm{NE}-b_{1} \mathrm{LW}^{0.73}$;

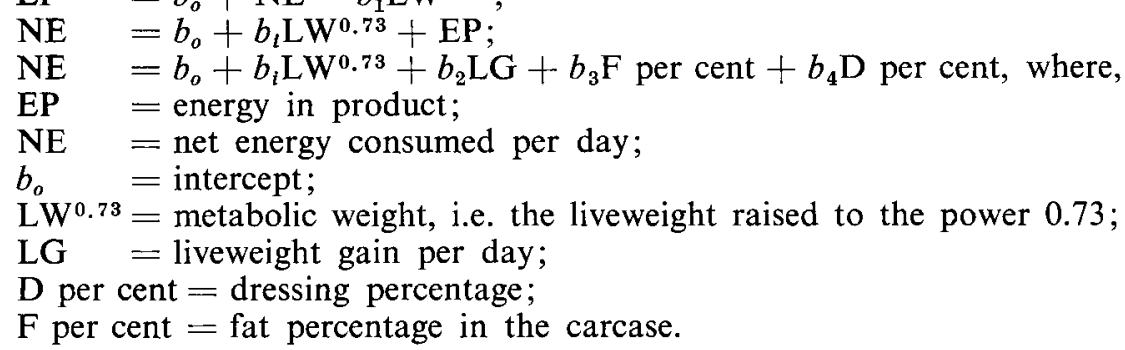

\section{Experiment 1. (Weight interval from $180-540 \mathrm{~kg}$ )}

Factorial experiment with four feeding levels (ad libitum, 85 p. 100, 70 p. 100 and 55 p. 100) and seven slaughter weights, $(180,240,300,360,420,480$ and $540 \mathrm{~kg}$ liveweight). It comprised 165 male calves of Red Danish evenly distributed in progeny groups from four sires (for details see ANDERSEN, 1975).

The data were analysed according to the following models:

(2) $\mathrm{KJ} /$ Day $=\alpha+$ feeding level $+b_{1}$. weight ${ }^{0.73}$ (within feeding level) $+\mathrm{b}_{2}$. daily gain.

(3) $\mathrm{KJ} /$ Day $=\alpha+$ feeding level $+b_{1}$. weight ${ }^{0.73}$ (within feeding level) $+b_{2}$. daily gain $+b_{3}$. dressing percentage $+b_{4}$. fat percentage.

The $b_{1}$-value for the four feeding levels in the two models was estimated as:

\begin{tabular}{|c|c|c|c|}
\hline & & Model (2) & Model (3) \\
\hline $\begin{array}{l}\text { ad libitum } \\
85 \text { per cent } \\
70 \text { per cent } \\
55 \text { per cent }\end{array}$ & $\begin{array}{l}\cdots \\
\cdots \\
.\end{array}$ & $\begin{array}{l}556 \pm 12 \\
419 \pm 12 \\
350 \pm 12 \\
287 \pm 12\end{array}$ & $\begin{array}{l}532 \pm 15 \\
401 \pm 14 \\
342 \pm 12 \\
282 \pm 13\end{array}$ \\
\hline
\end{tabular}

The results clearly demonstrated that the maintenance requirements (or the weight dependent use of non-productive energy) increases with increasing feeding level.

\section{Experiment 2. (Weight interval from $300-550 \mathrm{~kg}$ ).}

The experiment was phase $I$ in the Danish crossbreeding experiment and it included the following 8 sire breeds used on Red Danish and Black and White Danish cows : Simmental, Charolais, DRK, Romagnola, Chianina, 
Hereford, Blond d'Aquitaine and Limousin. Crossbred male progeny were tested in a young bull system with handfeeding of concentrate to appetite and with three slaughter points $(300 \mathrm{~kg}, 12$ months and 15 months). That part of the experiment included a total of 307 young bulls with individual records of feed consumption and complete carcase dissection. (For details see ANDERSEN et al. 1976). The data were analysed according to the following two models :

(4) $\mathrm{KJ} /$ Day $=\alpha+$ year + sire breed $+b_{1}$. weight ${ }^{0.73}$ (within sire breed) $+b_{2}$. daily gain.

(5) $\mathrm{KJ} /$ Day $=\alpha+$ year + sire breed $+b_{1}$. weight $\mathrm{t}^{\mathbf{0 . 7 3}}$ (within sire breed) $+b_{2}$. daily gain $+b_{3}$. dressing per cent $+b_{4}$. fat per cent.

The $b_{1}$-value for the eight sire breeds in the two models were estimated as:

\begin{tabular}{|c|c|c|c|c|c|c|}
\hline \multirow[b]{2}{*}{ Simmental } & \multirow[b]{2}{*}{$x$} & \multirow[b]{2}{*}{. } & \multicolumn{2}{|l|}{ Model (4) } & \multicolumn{2}{|l|}{ Model (5) } \\
\hline & & & $548 \neq 19$ & 5) & $477 \pm 20$ & 5) \\
\hline Charolais & $x$ & . & $523 \pm 19$ & 3) & $457 \pm 20$ & 3) \\
\hline DRK & $x$ &... & $560 \pm 20$ & 6) & $474 \pm 23$ & 4) \\
\hline Romagnola & $x$ & 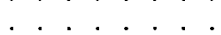 & $569 \pm 21$ & 8) & $494 \pm 22$ & 7) \\
\hline Chianina & $x$ & . & $562 \pm 21$ & 7) & $496 \pm 22$ & 8) \\
\hline Hereford & $x$ & 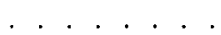 & $521 \pm 22$ & 2) & $426 \pm 25$ & 2) \\
\hline Blond d'Aquitaine & $x$ & $\therefore$ & $527 \pm 22$ & 4) & $480 \pm 22$ & 6) \\
\hline Limousin & $x$ & . . . . & $496 \pm 26$ & 1) & $417 \pm 27$ & 1) \\
\hline
\end{tabular}

In both models Hereford and Limousin showed the lowest and Chianina and Romagnola the highest maintenance requirement. When the data were adjusted to constant dressing p. cent and fat p. cent (Model 4), the b-value decreased, especially for Hereford and DRK crosses with the highest increase in fat percentage in the carcases during the test period.

\section{Experiment 3 (Weight interval from 320 to $560 \mathrm{~kg}$ ).}

Phase II in the Danish crossbreeding experiment included the following 10 sire breeds used on Red Danish and Black and White Danish cows : Black and White Danish, Aberdeen Angus, Gelbvieh, Piedmontese, South Devon, Brown Swiss, West Flemish Red, Middle and Upper Belgium and Red Danish. Crossbred male progeny were tested in a young bull system with three feeding levels, ad libitum, 85 p. cent and 70 p. cent), and three slaughter weights $(320 \mathrm{~kg}$, $440 \mathrm{~kg}$ and $560 \mathrm{~kg}$ ). This part of the experiment included a total of 409 young bulls with individual records of feed consumption and complete carcase dissection.

The data were analysed according to the following models :

(6) $\mathrm{KJ} /$ Day $=\alpha+$ year + sire breed + feeding level $+b_{1}$. weight ${ }^{0.73}$ (within sire breed) $+b_{2}$. daily gain.

(7) $\mathrm{KJ} /$ Day $=\alpha+$ year + sire breed + feeding level $+b_{1}$. weight ${ }^{\mathbf{0 . 7 3}}$ (within sire breed) $+b_{2}$. daily gain $+b_{3}$. dressing per cent $+b_{4}$. fat per cent. 
(8) $\mathrm{KJ} /$ Day $=\alpha+$ year + sire breed + feeding level $+b_{1}$. weight $\mathrm{t}^{0.73}$ (within feeding level) $+b_{2}$. daily gain.

(9) $\mathrm{KJ} /$ Day $=\alpha+$ year + sire breed + feeding level $+b_{1}$. weight ${ }^{0.73}$ (within feeding level $)+b_{2}$. daily gain $+b_{3}$. dressing per cent $+b_{4}$. fat per cent.

\begin{tabular}{|c|c|c|}
\hline & Model (6) & Model (7) \\
\hline 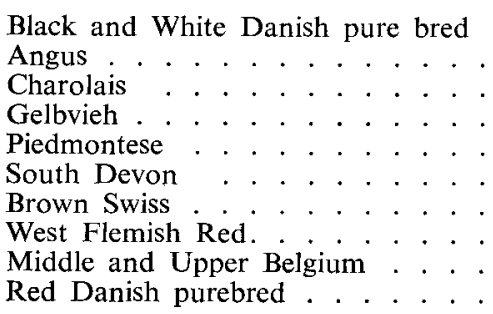 & $\begin{array}{l}438 \pm 21 \\
464 \pm 25 \\
439 \pm 23 \\
433 \pm 28 \\
467 \pm 26 \\
431 \pm 26 \\
434 \pm 28 \\
400 \pm 26 \\
464 \pm 27 \\
425 \pm 20\end{array}$ & $\begin{array}{l}393 \pm 22 \\
398 \pm 28 \\
413 \pm 23 \\
387 \pm 28 \\
449 \pm 25 \\
378 \pm 28 \\
384 \pm 29 \\
356 \pm 26 \\
433 \pm 27 \\
389 \pm 21\end{array}$ \\
\hline Feeding level & Model (8) & Model (9) \\
\hline 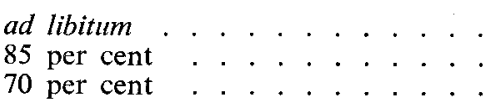 & $\begin{array}{l}541 \pm 15 \\
468 \pm 11 \\
355 \pm 11\end{array}$ & $\begin{array}{l}504 \pm 17 \\
434 \pm 13 \\
330 \pm 13\end{array}$ \\
\hline
\end{tabular}

\section{Experiment 4. (Weight interval from 50 to $340 \mathrm{~kg}$ )}

In the progeny test for beef production 10 bull calves per sire group were tested in the period from 4 weeks of age to a liveweight of $340 \mathrm{~kg}$.During the test the calves were fed concentrates ad libitum from individual feed hoppers. Every 28 days the calves were weighed and the feed consumption registered. A total of 30 progeny groups were included in the analysis and the maintenance requirements for the individual bull calves were calculated as (LARSEN, 1979) : (10) $\mathrm{KJ} /$ Day $\alpha+b_{1}$. weight ${ }^{0.73}+b_{2}$. daily gain, where $\mathrm{KJ} /$ Day and weight are averages of the successive 28 day periods. For some of the progeny groups the average $b_{1}$-value is shown in the following.

\begin{tabular}{|c|c|c|}
\hline Name of sire & No. of progeny & Average $b_{1}$-value \\
\hline $\begin{array}{l}\text { SDJ Rex } . . . \\
\text { Prince Red } . .\end{array}$ & $\begin{array}{l}9 \\
8 \\
9 \\
9 \\
9\end{array}$ & $\begin{array}{l}633 \\
677 \\
698 \\
707 \\
723\end{array}$ \\
\hline
\end{tabular}

The b-values are higher than those found in the other experiments. The reasons can be : 
1) all animals were on ad libitum feeding,

2) the weight/age interval was lower than in the other experiments,

3) no adjustment was made for increase in fatness during the growth period.

However, a high within breed variation in maintenance requirement is demonstrated and the coefficient of heritability on $b_{1}$-value is estimated to 0.31 .

\section{III. - Discussion and Conclusion}

In both the dairy and the beef production industry the main part of the food consumed is used for maintenance of the animals.

The results from the feeding trials described showed that even with constant daily feed intake, constant daily gain and constant composition of the gain, an important variation in maintenance requirements exists between feeding levels as well as between genotypes. It is therefore possible to manipulate the energy cost of growth by selection of breeding animals and by regulation of the feeding intensity.

Measuring maintenance requirement by use of respiration chambers is difficult and costly and therefore not a useful technique in testing and selection of breeding animals. It seems possible, however, as shown in Experiment 4, with regular recordings of feed intake and weight gain during the test period, to estimate the weight dependent maintenance requirement. It might be possible and valuable to include such a technique in the performance test of young breeding bulls in future.

Where energy standards for growing animals are concerned, it seems obvious that both the feeding intensity and the genetic potential of the animals must be taken into consideration.

\section{Acknowledgements}

Thanks are due to the Danish Meat Research Institute, Roskilde, who carried out jointing and tissue separation in the Danish experiments as well as thanks to Mr. JUST JENSEN for valuable assistance with the statistical analyses.

\section{References}

ANDERSEN. B.B. 1977a. Genetic investigations on growth, body development and feed utilization in dual purpose cattle. Diss. Copenhagen. $137 \mathrm{pp}$.

Andersen B.B. Liboriussen T., Thysen I., Kousganrd K., Buchter L. 1976. Crossbreeding experiment with beef and dual purpose sire breeds on Danish dairy cows. Livest. Prod. Sci., 3, 227-238.

Andersen B.B., Jensen J., Stendaek B., Kousgaard K., Buchter L. 1979. Avlsstationerne for kødproduktion. 478. beretning fra Statens Husdyrbrugfors $\phi g$. Copenhagen, $101 \mathrm{pp}$.

ANDERSEN H.R. 1975. The influence of slaughter weight and level of feeding on growth rate, feed conversion, and carcass composition of bulls. Livest. Prod. Sci., 2, 341-355.

ANDERSEN H.R. 1978. Effect of energy level on growth and efficiency. Current topics in Veterinary Medicine, vol. 2 Patterns of growth and development in cattle. 393-412.

Hansson A., Brannang E., Claesson O. 1953. Studies on monozygous cattle twins XII. Body development in relation to heredity and intensity of rearing. Acta Agric. Scand., III, 61-95. 
LANGHOLZ H.-J., Jongeling C. 1972. Untersuchungen zum genetischen Aussagewert der stationären Nachkommenprüfung auf Mastleistung und Schlachtkörperwert beim Rind. Züchtungskunde, $44,368-384$.

LaNGlet J.-F., Gravert H.O., Rosenheim E. 1967. Untersuchugen über die Erblichkeit der Fleischeistung bei Schwarzbunten Rindern. Z. Tierz Züchtungsbiol., 83, 358-370.

LARSEN F. 1979. Appetit, foderudnyttelse og vedligeholdelsebehov hos voksende tyrekalve. Hovedopgave, Copenhagen. $48 \mathrm{pp}$.

Preston T.R., Willis M.B. 1970. Intensive beef production. Pergamon Press, New York, 544 pp.

TAYLOR St. C.S., Young G.B. 1968. Equilibrium weight in relation to feed intake and genotype in twin cattle. Anim. Prod., 10, 393-412.

VAN Es E.J.H. 1978. Nutritional efficiency of protein and fat deposition. Current topics in Veterinary Medicine, vol. 2. Patterns of growth and development in cattle. 361-382.

Webster A.J.F., Smith J.S., Crabtree R.M., Mollison G.S. 1976. Prediction of the energy requirements for growth in beef cattle. Anim. Prod., 23, 329-340.

Vermorel M., Bouvier J.C., GEAY Y. 1976. The effect of the genotype (normal and double muscle Charolais and Friesian) on energy utilization by growing cattle at 2 and 16 months of age. In : Energy metabolism of farm animals. EAAP Publ. 19, Clermont-Ferrand, 217-220. 


\title{
Discussion
}

\author{
Chair : H. BicKel (Switzerland)
}

J.M. Forbes $(U K)$. - On the question of the variability of the efficiency of utilisation of energy for maintenance, I wonder how much thought has been put into frequency of feeding. The higher the level of feeding, the more frequently does the animal eat, and vice versa. If that is the case, during the few hours following feeding the majority of the VFAs will be absorbed but it will not be until some hours later that the majority of the amino acids are absorbed. Therefore, in order to make efficient use of the amino acids, the energy must first be stored in fat and glycogen and then mobilised, which is an inefficient process. I would think, therefore, that with infrequent feeding the efficiency of fattening might be good but the efficiency of protein deposition might be poor. Then, as you move towards more frequent feeding, the efficiency of fattening might be poorer than expected (the point made in the presentation) but the efficiency of protein deposition might be greater. I just wonder to what extent frequency of feeding has been considered as a further variable in both of the approaches which have been talked about this afternoon.

A.J.H. VAN Es (The Netherlands). - First of all, you have the work of eating. If you have a grazing animal compared with an animal eating concentrates, the time spent eating is quite different. If you measure the heat output over 24 hours of each animal, the difference is not very considerable. So $I$ doubt if this point is really so important, particularly for a dairy cow which is producing a lot of protein anyway, and also utilising a lot of protein. I am not sure that it is true to say that VFAs are absorbed within the first few hours after eating and the amino acids not until much later.

H. Bickel (Switzerland). - I believe Dr. Webster's work showed some very minor discrepancies.

G. Alderman $(U K)$. - On a point of principle, when calculating maintenance metabolisable energy requirements, are people using the fasted body weight of the animal? I am presuming that fasting metabolisms are made on fasted body weights. In the work that my colleague and I did way back in the early $70 \mathrm{~s}$, we drew attention to this and our estimate was that the difference was a 10 per cent change in body weight. The ARC 1965 proposals shifted from fasted weights to liveweights without drawing attention to it, which in effect, was a 10 per cent safety factor. I just want to draw attention to that and to the fact that Dr. Andersen's paper was in $W^{0.73}$ not $\mathrm{W}^{0.75}$ and there was a 12 per cent difference between his fasting metabolism figures in $\mathrm{kJ} / \mathrm{kg} \mathrm{W}^{0.73}$ and those of Dr. Van Es. So, depending on what he was dividing by he could be 20 per cent out on the figures presented by Dr. Van Es. I will leave the two authors to say what it was that they did.

A.J.H. VAN Es. - The answer from me is quite simple because I don't like fasting metabolism very much nor maintenance metabolism at the maintenance feeding level. So my body weight values apply to the body weight of the growing animal - the fed animal. It is a different body weight than if the animal has been fasted for a week or so or is just at maintenance level.

G. Alderman. - Historically, in the literature, it is very difficult to ascertain whether the values quoted were determined on the fasted animal or on the fed animal.

A.J.H. VAN Es. - I agree.

H. BICKEL. - It has even been questioned whether we should take shrunk body weight instead of the liveweight for calculating the metabolic body weight on the one hand, and on the other hand, as with pigs, the power of $\frac{7}{8}$ instead of $\frac{3}{4}$. Do you think that we can agree to use this $\frac{3}{4}$ power or does anyone think that the value should be different for the growing animal than for the adult animal ? 
J.M. Forbes. - Certainly Brodie has been quoted as supporting the figure of 0.73 or thereabouts, somewhere between 0.70 and 0.75 , but that was really derived from a species comparison. Brodie also looked at the metabolic rate of growing cattle and found there that the best exponent was 0.6. If you look at the relationship between voluntary food intake and liveweight in growing cattle, the best exponent appears to be close to 0.6 . I am sure that Dr. Béranger will make the point to morrow that it is certainly less than 0.75 . I have examined some published data in which they had not worked out the exponent and it turned out to be 0.6 . I would not argue that 0.6 should be adopted but I would also argue against the rather blind adoption of 0.75 or 0.73 .

A.J.H. VAN Es. - I think the value of this exponent is just another thing which is changing but we don't really know what it should be. We can use an assumed constant and then see how other things work out but all these things are inter-related. Perhaps it is better to use the exponent $i$ which indicates that you are not exactly sure.

M. Vermorel (France). - We generally use the exponent 3 but we have not checked the validity of it. As far as I remember, in 1974 or 1976 Webster regressed the heat production on ME intake in growing steers and found an exponent close to 0.75. Also, I think the Rostock group obtained a lot of energy balance, more than 600, on growing bulls and when they regressed the energy gain on metabolisable energy intake they used 0.75. When they used different exponents they found about the same figures for the coefficient related to protein gain and fat gain. So I would not say that 0.75 is the best exponent but it is probably not too far wrong for growing ruminants.

B. Bech Andersen (Denmark). - I would just comment that I used 0.73 in accordance with tradition, it is not that $I$ want to fight for that power instead of 0.75 . Also, I agree completely with Dr. Van Es on the effects of changing f'rom 0.73 to 0.75 . The results and conclusions I have presented would be exactly the same.

A.J.H. VAN Es. - Betwen $700 \mathrm{~kg}$ and $500 \mathrm{~kg}$ there is an almost straight line. The differences are important near $100 \mathrm{~kg}$; there you have curvilinearity. Above $200 \mathrm{~kg}$ it does not matter so much so I don't think we should worry about it too much.

H. Bickel. - But is it true that on the whole, if you make a really comprehensive model as, for example, your model $\mathrm{C} 9$, that we should leave open what will be the best fit statistically in order to have the least residual standard deviation ?

A.J.H. VAN Es. - Yes, I agree because that animal is even a monogastric animal, maybe $100 \mathrm{~kg}$. Then there is the transition to the ruminant animal and I think we should start after the animal is really a ruminant - or just stop before it is so far. It has a different energy metabolism anyway with regard to volatile fatty acids.

G. Alderman. - I am sorry to muddy the water but in Blaxter's review of fasting metabolism he didn't finish up with 0.73 or 0.75 - it is lower than both those values. I think that is all I dare say at the moment; we will ask Sir Kenneth when he arrives.

J.M. Forbes. - In an animal at maintenance level, in general its heat losses will be proportional to its surface area which would give an exponent of 0.66 . However, in the animal which is gaining weight, more of the animal's metabolism and food intake is going to growth which is in some way proportional to the liveweight to the power 1 . Therefore you would expect that the faster the animal is growing, the higher the exponent.

A.J.H. Van Es. - I think the surface area law is not a law at all. You can have an animal at a higher temperature behaving completely differently.

J.M. Forbes. - And if it has got big ears, and big skin folds...

A.J.H. Van Es. - Yes, there are so many means of getting rid of heat, for instance, by evaporation by means of the lungs - I think that is a very important way of loss of heat by a ruminant.

H. Bickel. - Perhaps we can move a little on this question of modelling. Dr Van Es, mentioned that even if you have a comprehensive model, there is still some doubt about the 
different variables, whether they are really independent. You referred to the dependency of protein on the one hand and fat deposition on the other hand, in respect of protein intake. Could you comment further on that.

A.J.H. VAN Es. - It was not with regard to protein intake but with regard to protein deposition. A young animal, growing at $1 \mathrm{~kg} /$ day, produces much more protein than an older animal, relative to body weight. At high feeding levels the animal is growing more fat and therefore relatively laying down less protein, so retained energy, with regard to protein energy, is decreasing steadily, depending also on the genotype of the animal. So, you can say that that animal which is producing, relatively, more protein may have a higher rate of turnover. There is some evidence for that in the monogastric animal although it is not very clear. If there is a higher rate of turnover then efficiency of utilisation of $\mathrm{ME}$ for protein deposition will be lower, so why not include that in your model ? The older the animal, the less its turnover, so the higher the efficiency of the energy deposition.

J. L'Estrange (Ireland). - I would like to ask a question which I realise is naive. With regard to this concept of maintenance, which we are now showing may vary with breed, and may change with level of intake, is it not perhaps time to think that that is the wrong model, and that maintenance is something that is required by the animal which does not go into production, rather than trying to pick a rigid value ?

\section{H. BICKEL. - I would not say that that is a naive question at all.}

A.J.H. VAN Es. - I did not say that maintenance requirement changes very much with feeding level. Dr. Bech Andersen said so, but I wonder whether he really believes it. Your difference of 100 or 200 per cent at the two feeding levels; is this estimate of maintenance a good estimate; is it statistically reliable, what is your error of that $b_{1}$ value?

B. Bech Andersen. - Well, the first thing is that I prefer to call it "non-productive use of energy" instead of metabolic. On the question of the standard error, I would like to mention just two independent experiments from which we made our calculations. They are Experiment 1 and Experiment 3 in the paper. You can see how well they correspond with each other. So I would say that the reliability of the estimates is quite high.

K. RoHr (Federal Republic of Germany). - Listening to these two papers and taking into account the interpretation the Rostock group gives to its own work, I think one may come to the conclusion that the maintenance requirement is decreasing, not only with the pre-ruminant and ruminant animal, but also with the animal from $200-500 \mathrm{~kg}$. When using a constant factor for protein for the conversion of metabolisable energy into protein energy, this could be logical.

H.J. Oslage (Federal Republic of Germany). - You mean we could use a constant value for the protein deposition when working different maintenance requirements - higher maintenance requirements for younger animals.

\section{A.J.H. VAN Es. - That is Webster's approach.}

H.J. Oslage. - Or, you could go the other way round Dr. Van Es, and say, let us define maintenance requirement more clearly, define how to measure it, and then say, well, this is the maintenance requirement and all other influences now go into the yield. That might be more clear.

A.J.H. VAN Es. - Yes, you will find that in my paper but my final conclusion would then be, whatever you do, if you use one approach then use the whole approach, and not use one part of one approach with another part of a different approach, because then the two will not fit.

H. BiCKEL. - I would just like to clarify a point with regard to Dr. Bech Andersen's paper. You mention $\mathrm{kJ} / \mathrm{day}$, do you mean net energy calculated from feed units by a constant caloric value of 1 feed unit ?

B. Bech AnDersen. - It is net energy and it is calculated from feed units with a constant value per feed unit. 
H. BICKEL. - That explains quite a lot of your discrepancies I think.

G. Alderman. - I would just like to make the point that Blaxter's original ARC model was based on fasting metabolism and then it had a plane of nutrition correction on the metabolisable energy. Webster was using an entirely different model with no plane of nutrition correction in it. If you do this in a graphical form you will see that this is merely a different way of describing the same point in energy retention terms. In other words, do you come down a line to give your maintenance intercept, or do you come down a curve? You arrive at different points; one is the maintenance $M E$ intercept and the other is fasting metabolism divided by $k_{m}$. These are two different models which must not be confused. The difficulty is that in terms of the world of literature there are some hundreds of measurements of fasting metabolism and very few measurements of Webster's basal metabolism. So do you throw over 50 years work and just fasten on a few measurements in order to go into a new model?

H. Refsgatrd ANDERSEN (Denmark). - Certainly the maintenance requirement must be changed with the feeding level. In the experiment where we fed from 55 per cent up to 100 per cent feeding levels, at 55 per cent feeding levels we are quite near what Dr. Van Es and others mentioned as requirements for maintenance. During the whole feeding period the animals still grow $600 \mathrm{~g} / \mathrm{day}$. So the maintenance requirements must be reduced - that is quite sure. We can refer to Swedish experiments with identical twins they fed below maintenance requirements and still the heifers grew $200 / 300 \mathrm{~g} /$ day. So I think there must be differences depending on feeding levels.

H. BICKEL. - I don't think anyone would argue that this is not the case. We shali see that also in some papers which will be given tomorrow.

A. NeIMann-Sørensen (Denmark). - I worked with the twins that Dr. Andersen mentioned. We measured the heart rate and the rhythm of their breathing - it went down to nearly half. Nobody was in doubt that there was a difference. Animals on 55 per cent intensity were adapting to the low feeding level by reducing the maintenance requirement. You could see that they had longer coats - there was a whole pattern of adaptation. One way of adapting was by putting down the loss of heat and the total activity of the animal.

H. BICKEL. - And the heart rate was taken during the feeding so it is clear that the heart rate is correlated with the whole metabolism and the whole metabolism is correlated with feed intake. For me that would not be exactly a proof that the maintenance requirement is...

A. Neimann-Sørensen. - It was taken continuously - not during eating but when they were resting between feedings.

A.J.H. VAN Es. - We have to agree that an animal that is eating a lot is more active, but activity as such does not increase maintenance requirement so very much ; it can never explain the 50 per cent or 100 per cent difference coming out of these trials. In the Danish trials they used fattening units and I still wonder if that is not the explanation for the big difference. If you feed an animal at maintenance according to starch equivalents it will really get much more than what is necessary for maintenance.

A. NeImann-Sørensen. - What about the genetic influence, the influence of the breed ? I would like to hear some comments on that aspect.

M. Vermorel (France). - I would just like to draw attention to some work done last year by our colleague Colleau at Jouy-en-Josas. He was able to estimate the maintenance requirement and the efficiency of $\mathrm{ME}$ utilisation by growing bulls of differend breeds, and crossbred animals, between 10 and 18 months of age. The estimated maintenance requirement of the animals ranged from 550 for Charolais bulls and $636 \mathrm{~kJ} / \mathrm{kg}$ metabolic weight for Holstein and Friesian crossbred bulls. The ME efficiency for growth was very relevant ; it showed about a 20 per cent difference in maintenance requirement between these bulls of different genotypes fed ad libitum.

G. Aldofman. - Just to confirm the point that was being made about starch equivalents ; on the slide I showed before lunch, one of the columns was the starch equivalent system as we ran it in the UK. Certainly, in the same set of feeding trials which were used 
to devise our metabolisable energy system, it was the case that the starch equivalent system, as we were using it, was predicting a gain of about $100 \mathrm{~g} /$ day while the animals actually gained $500 \mathrm{~g}$. It was one of the important conclusions of our work in 1972, that the starch equivalent system was about $400 \mathrm{~g}$ out, near maintenance. I think those calculations would have been done fairly closely to the way in which the Danish ones were made.

A.J.S. VAN Es. - Dr. Vermorel, are you really sure that in that other French work in Jouy-en-Josas there is no interaction? Are you really sure that the difference between these animals fed ad libitum was due to maintenance, or could it have been due to other factors which were not included in the model?

M. Vermorel. - There are probably interactions but I think the results have been analysed accurately. I would add that the animals were fed the same diet. There were eight groups of animals, in fact, I have only given the extremes. The weight gains were similar. The composition of body gain was estimated by the comparative slaughter technique. The energy retained as protein ranged from 24 per cent in the Holstein Friesian bulls to about 30 per cent in the Charolais bulls.

On the subject of the efficiency of ME utilisation for growth, it decreased from about 49 per cent for the Holstein Friesian bulls to about 46 per cent in the Charolais bulls.

A.J.H. VAN Es. - I can't understand that you have a better precision in your estimates than \pm 10 per cent. If you add up all these errors it is impossible to be any better than that.

B. Bech Andersen. - Before we end the discussion I would just like to say that I am not being dogmatic about our figures but the fact remains that there are differences we will increase the maintenance requirement when we increase intensity. I also think that what I am talking about is a more practical management requirement. The third point is that in our experiments we have calculated the intake in $\mathrm{kg}$ of the different components of the ration. We have chemical analyses of samples of the animal feed and we would be pleased for colleagues to re-calculate the results in other systems. It would be very easy to do and we would be very interested to know the results. 